
AL-Qadisiyah Journal of pure Science
Vol.23 No. 2
Year 2018

\title{
Study the thermal dynamics of calcon dye adsorption on surfaces of natural materials
}

\section{Noor Mustafa. Kamal AL-Musawi}

chemistry department, College of Science, University of Kufa , Najaf, Iraq

Email: noorm.muhsin@uokufa.edu.iq

\section{Received:-7/6/2017}

Accepted:-4/10/2017

\begin{abstract}
:
Theresearch includes a study of the thermal dynamics of calcon dyeadsorption, by using Ultra-violetvisible spectroscopy technique ,Temperature has been investigated at (298-328k), The results obtained indicate that the adsorption of Calcon dye, increase with increase of temperature, In the other words, the adsorption process is endothermic and $\Delta \mathrm{H}$ is positive. The effect of the acid function was also studied, the results obtained were follows according to the sequence : $\mathrm{pH}: 7>9>5$
\end{abstract}

Keywords:

Calcon dye ; Adsorption ; pomegranatecrust ; Rice crust.

Chemistry Classifiication QD450-801 


\section{AL-Qadisiyah Journal of pure Science Vol.23 No. 2 Year

\section{1-Introduction}

Water pollution is any physical or chemical change in the quality of water, directly or indirectly, that adversely affects living organisms, makes water unsuitable for the required uses, and water pollution has a significant impact on the lives of the individual, the family and the community[1]. Water pollution is also defined as the contamination of rivers, oceans and lakes, as well as rainwater, wells and groundwater, rendering their waters untreated and unusable, for humans, animals, plants and other organisms [2]. Water is a vital requirement for humans and other living organisms, Water may be a major reason for ending life on earth if it is contaminated [3], Water pollution is divided into two main types. The first is natural pollution, which is show in changing the water temperature, increasing salinity, or increasing the suspended substances. The second type is chemical pollution, and its forms are varied, such as pollution with waste water, oil leakage and pollution of agricultural wastes such as pesticides and agricultural fertilizers[4,5].

Contaminated water contains substances other than their natural constituents, which may be solid soluble or suspended, dissolved organic or inorganic substances, or substances It is as accurate as a bacterial Or algae or parasites, thereby altering their natural, chemical or biological properties[6,7] .

There are different methods of water treatment, such as physical and chemical processes such as adsorption, ion exchange (eg activated carbon) [8,9] , chemical oxidation using ozone or hydrogen peroxide at high temperature and various membrane processes depending on applications that enhance the process using filters Different sizes under different Osmosis pressure This process is highly efficient in removing solid materials.

Calcon is a sodium salts, chemical formula $\left(\begin{array}{lllll}\mathrm{C}_{20} & \mathrm{H}_{13} & \mathrm{~N}_{2} & \mathrm{Na} & \mathrm{O}_{5} \mathrm{~S}\end{array}\right)(2-$ hydroxy-1-naphthylazo) 2-naphthol-4sulphonic acid and its scientific name Fig. (1) represents the structural formula of the dye[10].

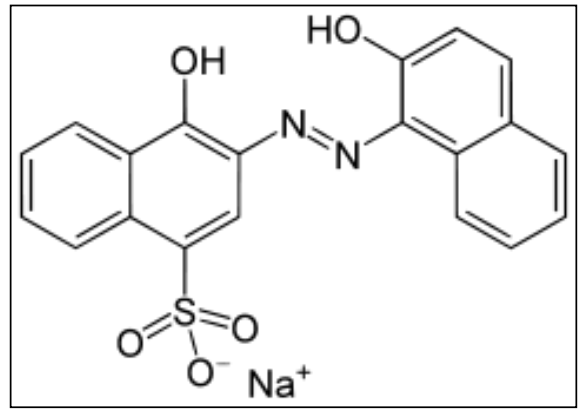

Fig (1) structure of the Calcondye

2-Experimental procedure

2-1- Chemical and Instruments.

Allchemical used in this study were supplied from different international companies such as Merch, Fluke and BDH chemicals company including Calcon dye , $\mathrm{NaOH}, \mathrm{HCl}$ and distilled water .Instruments ; UV- Visible Spectrophotometer , double Beam , Shlmadzu UV- Visible 1650 PC. Japan,

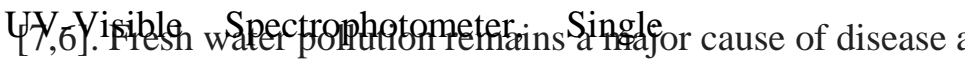
Beam, UV / VIS .ser.NO 030847 . USA, Water bath (GFL 1083),

2-2- Preparation of solutions: 


\section{AL-Qadisiyah Journal of pure Science $\quad$ Vol.23 No. 2 Year

Calcon dye $(0.05 \mathrm{~g})$ was dissolved in $(500$ $\mathrm{ml}$ )of distilled water to prepare a $100 \mathrm{ppm}$ solution. From this solution, diluted solutions (10-50) ppm were prepared by diluting after extracting the desired volume from the original solution and adding the distilled water to the desired size For calibrated calibration appointment.

\section{2-3- Determination of $\lambda \max$ and} CalibrationCurve:

It has been appointed wavelength that occurs has a higher absorption $(\lambda \max )$ for the solution of the dye being studied by recording absorption spectrum using spectroscopy visible rays and ultraviolet within the range of( $800-190) \mathrm{nm}$ and the use of quartzcell, and has been assigned a standard calibration, which represents the curve the relationship between absorbance and concentration through the preparation of solutions (10-50) ppm, according to the statement in fig (2) and measuring the absorbance of these solutions at the greatest wavelength $(568 \mathrm{~nm})$, and also has been measuring the absorbance of the solutions note above when centrist acid and baseband at wavelengths $(510 \mathrm{~nm}$, $532 \mathrm{~nm}$ ), respectively, as in doubt below[11].

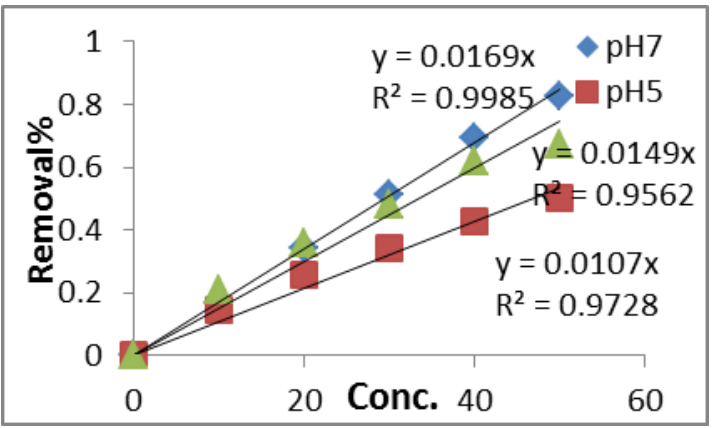

Fig (2) calibration curve of dye within pH (5-9)

\section{3- Result and discussion}

\section{3-1- Effect pH}

The effect of the acidic function of the water solution for the Calcon dye was studied in $\mathrm{pH}(9,5)$ and hydrochloric acid $(\mathrm{HCl})$ was used with a concentration of $\mathrm{N}$ $(1 \mathrm{~N}$ and $0.05 \mathrm{~N})$ and $\mathrm{NaOH}(1 \mathrm{~N})$ and $0.05 \mathrm{~N}$ to adjust the acidity of the water solution for 30 minutes and use $15 \mathrm{ml}$ of dye with a fixed weight of both surfaces $(0.3 \mathrm{~g})$,

Several previous studies[12], have shown that the adsorption efficiency of different compounds is significantlyaffected by the nature of the acidic function of the medium in which it is produced. The results showed that the acid function had a different effect on the Calcon adsorption on the surface of pomegranate crusts and rice crusts at $\mathrm{pH}$ (5.7) As shown in Tables (1) and (2) and Figs.( 3) and (4), the adsorption ratio was as high as possible in the natural acidic function of the water solution of the dye mentioned above. ( $\mathrm{pH}$ 7) and lower when the base solution is $(\mathrm{pH}$ 9) and lower with acid solution ( $\mathrm{pH} \mathrm{5)}$, these results can be explained depending on the charge of both surfaces and dye , Where the brightness used with neutral loads and in the neutral medium carries a positive charge. In the basic medium, this is due to the transformation of the hydroxyl group in these pigments to the phenoxy oxide ion. The presence of the negative charge on the oxygen atom in the phenoxy oxide makes it more susceptible to solubility within the solvent than its attraction to the surface of the masse material, thus reducing the adsorption potential[13]. 


\section{AL-Qadisiyah Journal of pure Science Vol.23 No. 2 Year

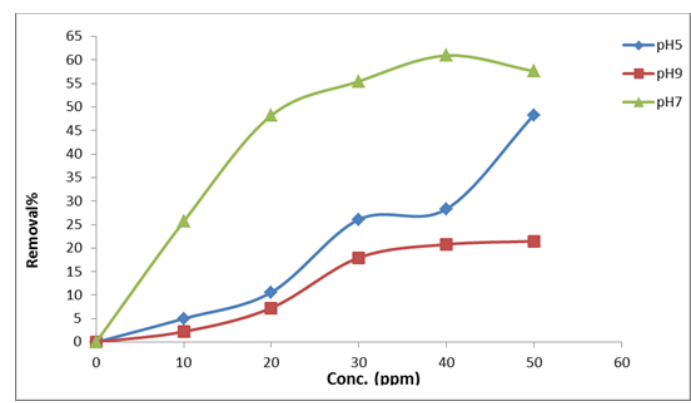

Fig (3) Effect pH on adsorptionofCalcon dye on the surface of pomegranate crust at temperature $\left(298 \mathrm{~K}^{\circ}\right)$.

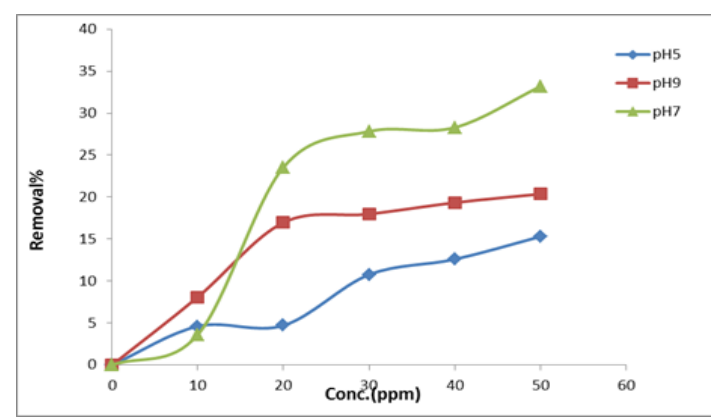

Fig (4) Effect pH on adsorption of

Calcon dye on the surface of the rice crusts at temperature $\left(298 \mathrm{~K}^{\circ}\right)$.

Table (1) Effect pH on adsorption of

Calcon dye on the surface of pomegranate crusts at temperature

$\left(298 K^{\circ}\right)$.

\begin{tabular}{|c|c|c|c|}
\hline $\begin{array}{c}\text { Conc. } \\
\text { (ppm) }\end{array}$ & $\begin{array}{c}\text { Removal. } \\
\text { \% } \mathbf{p H ~ 5}\end{array}$ & $\begin{array}{c}\text { Removal. } \\
\mathbf{\%} \mathbf{p H ~ 9}\end{array}$ & $\begin{array}{c}\text { Removal. } \\
\mathbf{\%} \mathbf{p H} \text { 7 }\end{array}$ \\
\hline 0 & 0 & 0 & 0 \\
\hline 10 & 5 & 2.24 & 25.66 \\
\hline 20 & 10.6 & 7.27 & 48.19 \\
\hline 30 & 26.08 & 17.96 & 55.45 \\
\hline 40 & 28.3 & 20.79 & 60.93 \\
\hline 50 & 48.3 & 21.46 & 57.62 \\
\hline
\end{tabular}

$\log X m=-\frac{\Delta H}{2,303 R T}+$ conc.

Table (2) Effect pH on adsorption ofCalcon dye on the surface of the rice crusts at temperature $\left(298 \mathrm{~K}^{\circ}\right)$.

\begin{tabular}{|c|c|c|c|}
\hline $\begin{array}{c}\text { Conc. } \\
\text { (ppm) }\end{array}$ & $\begin{array}{c}\text { Removal. } \\
\text { \% pH 5 }\end{array}$ & $\begin{array}{c}\text { Removal } \\
\text { \% pH 9 }\end{array}$ & $\begin{array}{c}\text { Removal } \\
\text { \% pH 7 }\end{array}$ \\
\hline 0 & 0 & 0 & 0 \\
\hline 10 & 4.6 & 8.09 & 3.61 \\
\hline 20 & 4.7 & 16.96 & 23.54 \\
\hline 30 & 10.75 & 17.97 & 27.82 \\
\hline 40 & 12.58 & 19.33 & 28.28 \\
\hline 50 & 15.29 & 20.36 & 33.17 \\
\hline
\end{tabular}

\section{3-2- Effect of temperature}

The effect of temperature in the process of adsorption of dye on the surface of pomegranate crusts and rice crusts was studied at a certain temperature range (2555) $\mathrm{C}^{\circ}$, where $15 \mathrm{ml}$ of dye was used with a fixed weight of both surfaces $(0.3 \mathrm{~g})$ and 30 minutes, Showed results that were obtained in the fig (5) and (6) and tables (3) and (4) below the effect of temperature on the rate of adsorption of the dye Calcon surfaces pomegranate crusts and rice crusts in over temperature (328-298) $\mathrm{K}^{\circ}$ as found that increasing the temperature increases the efficiency of the adsorption means that the process is endothermic process and this indicates the presence of the absorption as well as adsorption process as increasing the temperature adsorbed on the surface spread to the inside of the pores and increases the speed of deployment [14], this phenomenon is called merger (Incorporation), was $\Delta \mathrm{H}$ draw the logarithm of the greatest amount of adsorbed $\log \mathrm{Xm}$ versus inverted absolute temperature $1 / \mathrm{T}$ using an account Entries to the values, according to the following equation[15] :

A linear relationship was obtained as in Figures (7) and (8), and the value of 
AL-Qadisiyah Journal of pure Science $\quad$ Vol.23 No.2 Year

$\Delta \mathrm{G}$ was obtained from the following equation [16] :

The entropy values were obtained through the following equation[17]:

Table (5) shows the values of $\Delta H, \Delta \mathrm{S}$ and $\Delta \mathrm{G}$ at different temperatures.

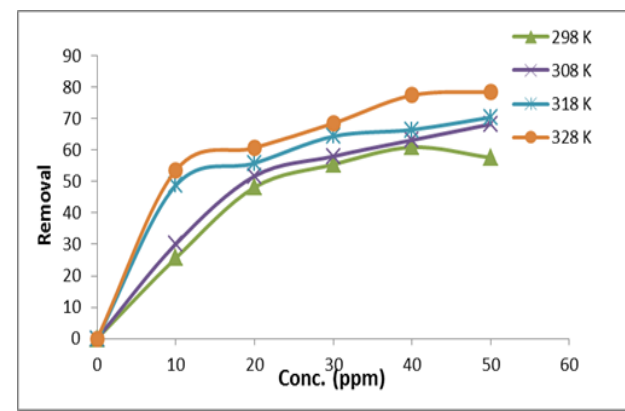

Fig. (5) Effect of temperature on adsorption of Calcon dye on the surface of pomegranate crust at different temperature

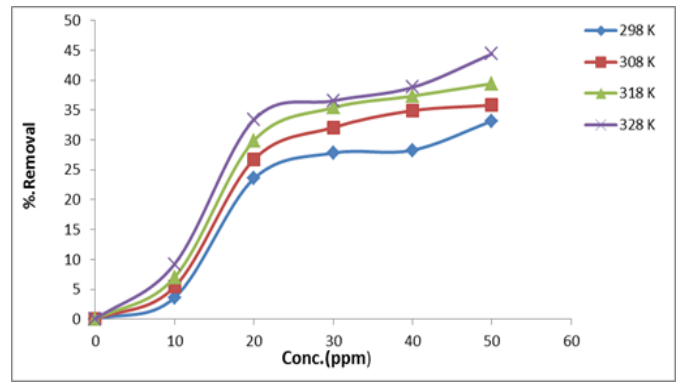

Fig. (6) Effect of temperature on adsorption of Calcon dye on the surface of rice crust at different temperatures.

Table (3) Effect of temperature on adsorption of Calcon dye on pomegranate crust at different temperature.

\begin{tabular}{|c|c|c|c|c|}
\hline $\begin{array}{l}\text { Con. } \\
\text { ppm }\end{array}$ & $\Delta G_{\text {Removal. }} \underset{\%}{\stackrel{298 \mathrm{~K}}{\bar{e}} R T}$ & $\ln _{\mathrm{Re}} \frac{308 \mathrm{~K}}{\mathrm{Cm}_{\%}}$ & $\begin{array}{c}318 \mathrm{~K} \\
\text { Removal. } \\
\%\end{array}$ & 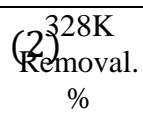 \\
\hline 0 & 0 & 0 & 0 & 0 \\
\hline 10 & 25.66 & 30.12 & 48.79 & 53.61 \\
\hline 20 & 48.19 & 51.74 & 55.88 & 60.75 \\
\hline 30 & $\Delta G 5: 45 \Delta H$ & $-5 \mathrm{~B} \cdot \mathrm{aS}$ & 64.39 & (3) 68.55 \\
\hline 40 & 60.93 & 63.2 & 66.52 & 77.48 \\
\hline 50 & 57.62 & 68.28 & 70.46 & 78.57 \\
\hline
\end{tabular}

Table (4) The effect of temperature on the absorption of Calcon dye on the surface of rice crusts at different temperatures

\begin{tabular}{|c|c|c|c|c|}
\hline $\begin{array}{c}\text { Conc } \\
\text { ppm }\end{array}$ & $\begin{array}{c}298 \mathrm{~K} \\
\text { Removal. } \\
\%\end{array}$ & $\begin{array}{c}308 \mathrm{~K} \\
\text { Removal. } \\
\%\end{array}$ & $\begin{array}{c}318 \mathrm{~K} \\
\text { Removal. } \\
\%\end{array}$ & $\begin{array}{c}328 \mathrm{~K} \\
\text { Removal. } \\
\%\end{array}$ \\
\hline 0 & 0 & 0 & 0 & 0 \\
\hline 10 & 3.61 & 5.42 & 7.02 & 9.22 \\
\hline 20 & 23.54 & 26.74 & 29.9 & 33.41 \\
\hline 30 & 27.82 & 32.1 & 35.4 & 36.57 \\
\hline 40 & 28.28 & 34.92 & 37.36 & 38.81 \\
\hline 50 & 33.17 & 35.83 & 39.44 & 44.41 \\
\hline
\end{tabular}

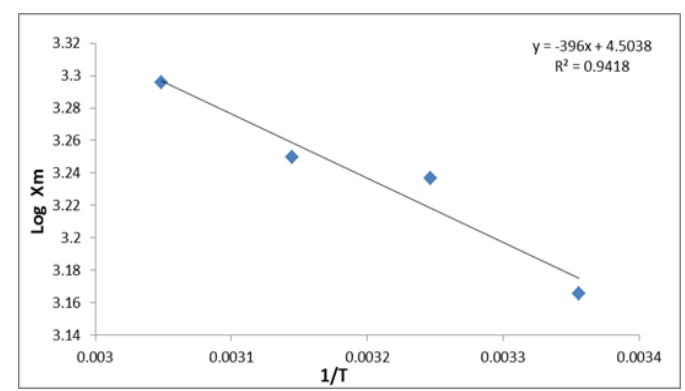

Fig. (7) Plot of Log Xm versus1/T of adsorption on the pomegranate crust surface. 


\section{AL-Qadisiyah Journal of pure Science Vol.23 No. 2 Year

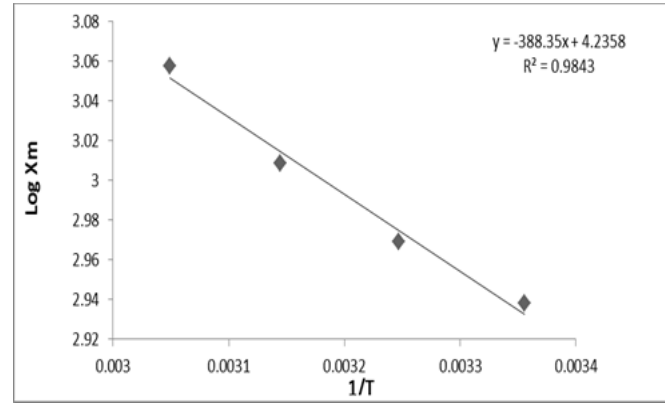

Fig. (8) Plot of Log Xm versus1/T of adsorption on the rice crust surface.

Table (5) Thermodynamic function values $\Delta G^{\prime} \Delta H^{\prime} \Delta$ Sfor Calcon dye at 298K .

\begin{tabular}{|c|c|c|c|}
\hline $\begin{array}{c}\text { Adsorba } \\
\text { te }\end{array}$ & $\begin{array}{c}\Delta \mathrm{G} \\
\mathrm{kJmole}^{-1}\end{array}$ & $\begin{array}{c}\Delta \mathrm{H} \\
\mathrm{kJmole}^{-1}\end{array}$ & $\begin{array}{c}\Delta \mathrm{S} \\
\mathrm{Jmole}^{-1} \mathrm{~K}^{-} \\
1\end{array}$ \\
\hline $\begin{array}{c}\text { pomegra } \\
\text { nate } \\
\text { crusts }\end{array}$ & -10.55 & 7.58 & 60.83 \\
\hline $\begin{array}{c}\text { rice } \\
\text { crusts }\end{array}$ & -8.12 & 7.43 & 52.18 \\
\hline
\end{tabular}

4- adsorption Isotherm.

Freundlich and Langmuir is one of the most widely used isotherms, which represents the relationship between the amount of material absorbed on a surface and the concentration or pressure of equilibrium at a given temperature. The equation of Freundlich and Langmuir is expressed in the following linear relationship $[18,19]$

Since non-absorbent, the concentration of the substance Ceq and the amount of the absorbent substance qeq and Freundlich constant are $\mathrm{K}$ and $\mathrm{n}$, The Log Xm versus Log Ceq graph gives a straight line with a slope of / $\mathrm{n} 1$, which is a measure of adsorption intensity, and a $\log \mathrm{K}$ section that represents a adsorption capacitance function,Figj.(9) represents the Freundlich and Langmuir equation for adsorption of pigment on the surface of pomegranate crusts and rice crusts

The equation of Langmuir is expressed[20,21] :

$$
\frac{C e q}{X m}=\frac{1}{k}+\left(\frac{a}{k}\right) C e q
$$

As:

$\mathrm{k}$ is equal to the Isotherm constant of Langmuir and $\mathrm{Xm}$ is adsorption capacity. The values of $\mathrm{k}$ and a can be calculated from the graph of the linear relationship between Ceq versus Ceq / Xm which gives (a/k) and slope $1 / \mathrm{k}$,Fig. (10) represents the Langmuir equation for adsorption of pigment on the surface of pomegranate crusts and rice crusts .

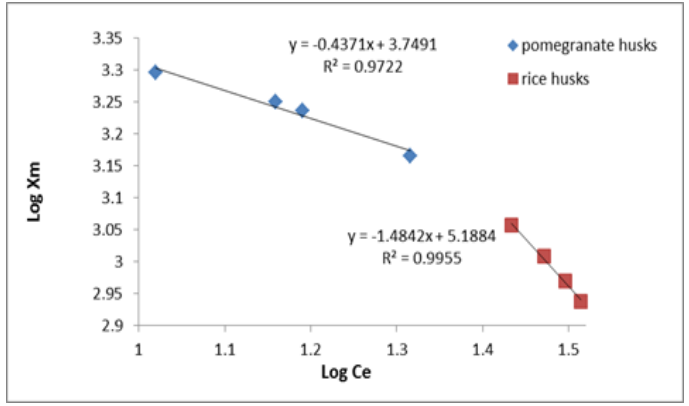

Fig. (9) Freundlich - Langmuir isotherm for adsorption of pigment on the surface of pomegranate crusts and rice crusts.

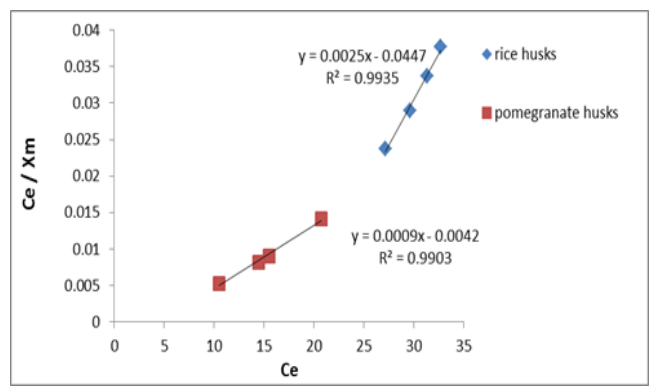




\section{AL-Qadisiyah Journal of pure Science $\quad$ Vol.23 No. 2 Year

\section{Fig. (10) Langmuir adsorption isotherm of dye on the surface of pomegranate crusts and rice crusts.}

\section{References :}

1- Bhatkhande,D.S.,V.G.angarkar, A.C.M. Beenackers,(2002)‘Photocatalytic degradation for environmentalapplications A Review. J. Chem. Technol. \& Biotech، 116-102(1)77.

2- Ollis, D.F., E. Pelizzetti, N. Serpone,(1991), Destruction ofwater contaminants . Environ. Sci. Technol., 25, 1523-1529.

3- Balcioglu, I. and Arslan, I. (2001). "Partial oxidation ofdyestuffs and dioxide.J. Catal., 111,264-272.

4- Inel, Y.,Okte A., (1996).Photocatalytic degradation ofmalonic acid in aqueous suspensions of $\mathrm{TiO}_{2}$ : an initialkinetic investigation of $\mathrm{CO}_{2}$ photogeneration. J. Photochem .Photobiol. A Chem. 96, 175-180.

5- Kudo,A., (2003).Photocatalyst Materials for Water Splitting,Cat. Surv. from Asia, 7,1 P.31 .

6- Bhatkhande, D.S., Pangarkar, V.G., Beenackers ،A.A.C.M. , (2001).Photocatalytic degradation forenvironmental applications areview.(J.ofChem. Tech.

and Biotechnology 77:102-116.

7- Hoffmann, A. J., E.R. Carraway, M.R. Hoffmann (1994).Photocatalytic production of $\mathrm{H}_{2} \mathrm{O}_{2}$ and organic peroxides onquantum-sized semiconductor colloids.Environ. Sci. Technol. , 28, 776-785.

8- Hoffmann .M.R., Martin .S.T.,Choi W.,
Environmental applicationof semiconductor photocatalysis,.Chem. Rev. 95 69-96.

9- Takahashi, Kiyoshi; Yoshikawa, Akihiko; Sandhu . 'Adarsh, Wide bandgapsemiconductors:

fundamental properties and modern photonic and electronic devices.(2007).Springer. p. 357. ISBN 3-540-47234-7.

10- HolzbecherZ.,Divis. L., M. Kral, S. Ladislav, F. Vlacil، . (1976) . Handbook ofOrganic Reagent in Inorganic Analysis‘ElllisHorwood, p.621.

11-RastegarzadehS. * andMoradpour Z. . ( 2009). Optical pH Sensor Based onCalconImmobilization Membrane , . Department ofChemistry, College of Science,ShahidChamran University, Ahvaz, Iran , J.Iran. Chem. Soc., Vol. 6, No.4December, pp. 857-862.

12- Al-Hyali.E. A., O. Ramadhan and S. A. Al-Dobone(2004).Effect ofsubstituentstype on the adsorption of aromatic carboxylic and their relation to concentration, temperature and $\mathrm{pH}$, Accepted forPublication byRaf. Jour .Sci,

13- Al-Jarjary.I. A.,(2005) "Study of thefactors affecting the Adsorption of same Azo Dyes complexes and calculationsof the thermodynamicfunctions "M.Sc.Thesis, Mosul University.

14- Geetha.K.S.; and Belagali, S. L. (2010 ).Adsorption studies of potassium permanganate and dyes using egg shell as an adsorbent TheEkologia, 10. 1- 2.pp: $31-40$.

Bahenemann.D.W,(1995) 


\section{AL-Qadisiyah Journal of pure Science Vol.23 No. 2 Year

15- Aljilawi.L. H.,(2005). Adsorption of some pigments on the surface of the white Iraqi kaolin clay.Master Thesis. Kufa University. College of Education for Girls.

16-Diab. R. M.(2006).,Thermodynamic study on some industrial and woolen fabrics ,Master Thesis, University of Kufa, Faculty of Science.

17-Baskaran , P. k . ; Venkaramen, B. R . and Saivoli, (2011) .Adsorption of malachite Green Dye and by acid activated carbon, Kinetic thermodynamic and Equilibrium studies , E. Journal of chemistry 8(1), PP : (9-18) .

18- Al-Abady.R.T.,

.Thermodynamic and kinetic study ofAdsorption of some Azo Dyes on Activated Carbon andother Developed Adsorbents, M. Sc. Thesis. MosulUniversity

19-Al-Sammrae. L. H.,Received 11 / 8 / 2008, Accepted 4/3/2009) Study Effect Opition Substituents on Adsorption 1,2,3-Methyl $\quad$ Azo- $\quad \beta$-Naphthol ,Department ofChemistry ,College of Education /Sammra, University of Tikrit, Tikrit, Iraq.

20- Adamson A.W. and Gast A.P.(2001) Physical Chemistry of Surfaces, 6th.Edition, Wiley, New York, 12p .

21- Perkowski J. and Kos L. (2003).Decolouration of model dye house wastewater with advanced oxidation processes, FibresandTextiles in Eastern Europe, 11, 67-71 
AL-Qadisiyah Journal of pure Science $\quad$ Vol.23 No.2 $\quad$ Year

\title{
دراسة الايناميكية الحرارية للامتزاز صبغة calcon على سطوح المواد الطبيعية
}

\author{
نور مصطفى كمال الموسوي \\ قسم الكيمياء ، كلية العلوم ، جامعة الكوفة ، نجف ، العراق . \\ Email: noorm.muhsin@uokufa.edu.iq \\ 2017/10/4: تاريخ القبول

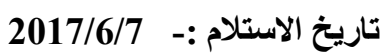

\section{الخلاصة}

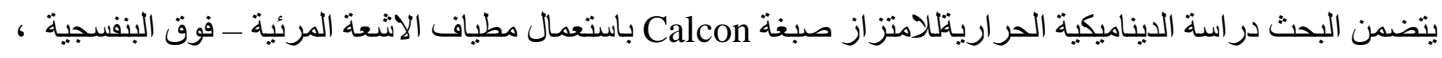

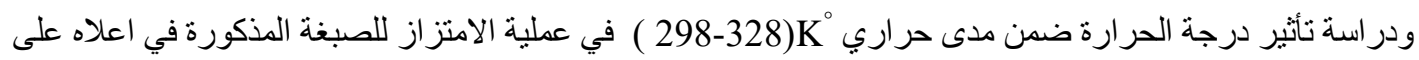

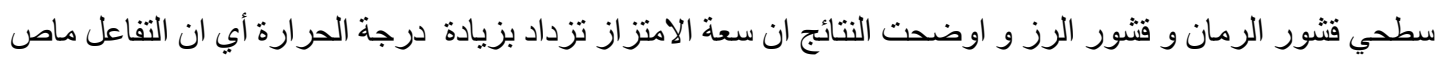

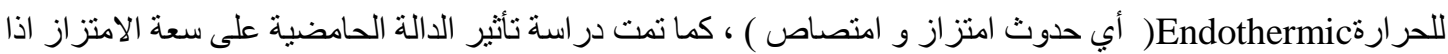

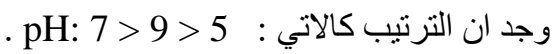
الكلمات المفتاحية : صبغة Calcon ، الامنز از ، قثنور الرمان ، قشور الرز . 